\title{
The Diversification Puzzle: The Role of Asymmetric Information and Insider Trading in Pakistan
}

\author{
Mushtaq Hussain Khan, Ahmad Fraz and Arshad Hassan*
}

\begin{abstract}
While corporate diversification is a fundamental issue both in the management literature and in corporate policy, the question that remains is whether it destroys or enhances firm value. This empirical study of the corporate diversification-value relationship for Pakistani firms looks at the role of asymmetric information and insider trading over a 10-year sample period, 2005-14. Using the industrial entropy index and purchase ratio to capture corporate diversification and insider trading, respectively, the study provides empirical evidence that questions the agency theory-based explanation of the corporate diversification-value relationship. Our results show that, in cases of asymmetric information, insiders increase the purchase of their firms' shares in the open market when diversification is high. This contradicts the corporate diversification-value destruction stance of agency theory as well as the idea that outside investors' undervaluation occurs due to information asymmetries. These results have strategic implications for corporate diversification strategies and are relevant to firm managers, regulators and shareholders.
\end{abstract}

Keywords: Corporate diversification, agency effect, information asymmetry, insider trading, Pakistan.

JEL classification: G14, G32.

\section{Introduction}

Understanding the nature and effects of corporate diversification has long been a fundamental issue in both the management literature and corporate policy. However, there is still no consensus on whether corporate diversification destroys or enhances firm value (Erdorf et al., 2013; Rudolph \& Schwetzler, 2013). The literature tends to show that managers seek to benefit themselves at the expense of firm shareholders through their corporate diversification strategies rather than pursing investments that would enhance firm value (see Jensen \& Meckling, 1976; Amihud \& Lev,

\footnotetext{
* Faculty of Management and Social Sciences, Mohammad Ali Jinnah University, Islamabad, Pakistan.
} 
1981; Fama \& Jensen, 1983; Denis, Denis \& Sarin, 1997; Aggarwal \& Samwick, 2003). Similarly, most companies do not diversify efficiently, which has an adverse impact on shareholders' wealth (Martin \& Sayrak, 2003).

Inefficient corporate diversification also gives managers a chance to increase their nonpecuniary benefits, the cost of which is borne by the firm's shareholders (McConnell, McKeon \& Xu, 2010). These personal or nonpecuniary benefits include empire building (Jensen, 1988), increased managerial compensation, which depends on firm size (Jensen \& Murphy, 1990) and self-preservation, which is achieved by utilizing their personal skills (Shleifer \& Vishny, 1989). A number of studies underline this corporate diversification-value destruction stance of agency theory, noting that a significant discounted value is associated with firms that are more diversified (see Lang \& Stulz, 1994; Berger \& Ofek, 1995; Lins \& Servaes, 1999; Denis, Denis \& Yost, 2002; Hund, Monk \& Tice, 2010; Hoechle et al., 2012). These results have led researchers to assume that diversification destroys firm value - this is known as the agency effect of corporate diversification.

However, the information effect of corporate diversification assumes there is not necessarily a conflict of interest between managers and shareholders when it comes to strategic decisions such as corporate diversification (Fox \& Hamilton, 1994; Davis, Schoorman \& Donaldson, 1997). In case of asymmetric information, shareholders may not be able to gauge managers' ability to make efficient decisions (Gomez-Mejia \& Wiseman, 2007) and the latter's diversification decisions may be mistaken for value-decreasing strategies by outside shareholders (Seyhun, 1986). This is the information effect of corporate diversification.

Ataullah et al. (2014) compare the effects of corporate diversification (agency and informational) for a sample of British firms. They argue that, when managers implement diversification strategies to benefit themselves rather than to increase firm value, they are less likely to purchase their own firm's shares in the open market (agency effect). Even if managers happen to be pursuing an efficient diversification strategy to enhance the firm's value, the prevailing information asymmetries may keep outside shareholders from perceiving this. In this case, managers are likely to purchase their firm's shares in the open market more actively (information effect).

Although there is a vast body of literature on the corporate diversification-value relationship in developed countries, these studies tend to neglect the issue in relation to developing countries. To the best of our knowledge, this is the first attempt to empirically investigate the corporate 
diversification-value relationship under asymmetric information and insider trading with reference to developing countries. Ataullah et al. (2014) raise two questions in this context. First, do insiders follow strategies for corporate diversification primarily to benefit themselves? Second, do outside investors believe that managers use diversification strategies solely to pursue personal benefits?

We conjecture that the results obtained by Ataullah et al. (2014) for the UK market do not necessarily apply to developing countries where financial markets are characterized by weak corporate governance/control and inadequate disclosure, which enhance agency problems, information asymmetries and insider trading. This argument is supported by Tsai, Young and Hsu (2011), who argue that developing markets in Asia have high information asymmetries and market inefficiencies such as less robust legal investor protection and disclosure systems.

This study is significant in that it compares the impact of corporate diversification - agency and informational - and explores the dominant effect of both on stock markets in developing countries. The two effects of corporate diversification have different practical implications for corporatelevel policies and the management literature. If the agency effect dominates whereby corporate diversification is considered a value-destructive strategy, this would call for steps to improve corporate governance to ensure that managers focus on the core competencies of their firm to increase value (Denis et al., 2002). If the information effect dominates, corporate diversification is unlikely to be considered a value-decreasing strategy. As a result, the focus would likely be on enabling corporate managers to realize the potential benefits of diversification strategies and to signal the value of these strategies to outside shareholders (Lane, Cannella \& Lubatkin, 1998).

The remainder of the study is organized as follows: Section 2 provides a literature review. Section 3 describes the dataset used. The study's variables and methodology are discussed in Sections 4 and 5. The results are analyzed in Section 6. The final section provides a summary and concluding remarks.

\section{Literature Review and Hypotheses}

Corporate diversification is defined as a combination of business units that operate in different industries under the common control of a single firm (Martin \& Sayrak, 2003). The considerable literature on corporate diversification and firm value looks at the agency effect, the role of 
asymmetric information and insider trading with respect to the corporate diversification-value relationship. In the case of the agency effect, the literature reports the existence of a significant discount associated with diversified firms and finds a negative relationship between diversification strategies and firm value.

Lang and Stulz (1994) were among the first to identify a diversification discount for diversified firms in comparison to a portfolio of focused firms. After adjusting the control variables for firm size, research and development (R\&D) expenses and access to financial markets, they find that diversified firms trade at a significant discount. Berger and Ofek (1995) report similar results for a sample of internationally diversified firms. They show that diversified firms trade at a 13-15 percent discount compared to focused firms. Similarly, Hund et al. (2010) examine a sample of firms for the period 1978 to 2005 and report a diversification discount of approximately 11 percent for all diversified firms.

Lins and Servaes (1999) use a sample of European firms to investigate the impact of corporate diversification on firm value. Except for German firms, the results are similar across all other European countries. Rudolph and Schwetzler (2013) report a diversification discount for continental Europe. Some studies focus specifically on the US market and find a significant diversification discount. For instance, Doukas and Kan (2006) study a sample of US firms between 1992 and 1997 and report a diversification discount of 12 percent for all diversified firms. Other studies by Claessens et al. (1998) and Lins and Servaes (2002) conducted for Asian economies also report significant discounts: 14 and 16 percent, respectively, for the diversified firms in their samples.

These results have several explanations. For instance, diversified firms may trade at a discount for risk reduction purposes (Mansi \& Reeb, 2002), institutional factors (Fauver, Houston \& Naranjo, 2003) or due to the impact of increasing leverage on firm value (Doukas \& Kan, 2006). Hoechle et al. (2012) note that diversification discounts are partly caused by poor corporate governance in addition to risk-reducing effects and agency problems. Recent studies argue that diversified firms trade at a discount due to merger and acquisition activities and their accounting implications (Custodio, 2014) as well as negative transfer effects (Zahavi \& Lavie, 2013).

This stream of research on corporate diversification also extends to Asian markets. For instance, Afza, Slahudin and Nazir (2008) assess the relationship between diversification and corporate performance for a 
sample of 65 Pakistani firms and find a negative relationship between the observed variables. Qureshi, Akhtar and Imdadullah (2012) also document a negative relationship between diversification strategies and firm performance for their sample. Grigorieva and Petrunina (2015) test whether mergers and acquisitions create value for shareholders in developing countries for the period 2003-09. They find a decline in the performance of combined firms after mergers and acquisitions have taken place.

These findings reveal that diversification destroys firm value. This argument is consistent with the agency effect of corporate diversification, which Ataullah et al. (2014) link to insider trading. They argue that, when managers implement diversification strategies to benefit themselves rather than to increase firm value (the agency effect), they are less likely to purchase their own firm's shares in the open market (insider trading). This points to a negative relationship between the corporate diversification strategies of managers and their propensity to purchase shares in their own firms. Based on this argument, if the agency effect of corporate diversification dominates the information effect, we assume:

Hypotheses 1 (H1): There exists a negative relationship between corporate diversification and insider trading.

On the other hand, the information effect suggests that managers usually implement diversification strategies to enhance firm value, but that information asymmetries lead external investors to undervalue these strategies. Thomas (2002) argues that corporate diversification influences the level of information asymmetry between managers and shareholders. This argument is consistent with the information transparency hypothesis pioneered by Hadlock, Ryngaert and Thomas (2001), who argue that managers have access to segment-level information on cash flows in diversified firms while outsiders have less value-relevant information.

The literature also reports that corporate insiders acquire an informational advantage by purchasing undervalued 'value stocks' and selling overvalued 'growth stocks' (Rozeff \& Zaman, 1998). Such purchases convey insiders' private, firm-specific favorable information to the market, while insider sales convey their private, firm-specific unfavorable information to the market (Fidrmuc, Goergen \& Renneboog, 2006). Agarwal and Singh (2006) argue that insiders usually hold private information and take market positions (long or short) based on these specific sets of information. Piotroski and Roulstone (2005) report a negative relationship 
between insider purchases and firms' current performance and a positive relationship with firms' future performance.

Insider trading is dependent on firm-specific attributes that determine the information asymmetries between insiders (managers) and outside investors (Jeng, Metrick \& Zeckhauser, 2003). One of these attributes is R\&D expenditure. Coff and Lee (2003) note that firms engaging in R\&D face more reaction from the market because outside investors are unable to value these tacit projects correctly with the relatively little information available to them. Following financial analysts also decreases insiders' informational advantage over outside investors (Frankel \& Li, 2004).

Jagolinzer, Larcker and Taylor (2011) find that active monitoring by the general counsel is linked to a significant reduction in insider trading profits and in the ability of insider traders to predict earnings surprises. Skaife, Veenman and Wangerin (2013) link the quality of internal control to insider trading and find that its profitability is considerably greater in firms that disclose material weaknesses in internal control than in firms wielding effective control. Joseph and Wintoki (2013) report that insider profits are substantially higher among firms characterized by advertising investments relative to firms that have no advertising investments. Cziraki, De Goeij and Renneboog (2014) argue that governance rules influence insider profitability and that insider transactions are more profitable among firms where shareholder rights are not restricted by anti-shareholder mechanisms.

Alldredge and Cicero (2015) note that, among firms with a concentrated sales relationship, insiders appear to sell their own stock profitably based on public information on their principal customers. It is widely accepted that this insider trading conveys private information to outside investors (John \& Lang, 1991; Fidrmuc et al., 2006) and provides credible signals to the market on the value relevance of various corporate events such as investment expenditure and dividend policy (Damodaran \& Liu, 1993).

These findings reveal that, in case of information asymmetries, managers (insiders) implement corporate strategies to increase firm value and this argument is consistent with the information effect. Within this strand of research, Ataullah et al. (2014) link the information effect of corporate diversification to insider trading through asymmetric information. They argue that managers may be pursuing an efficient diversification strategy to enhance their firm's value, which the prevailing information asymmetries prevent outside shareholders from grasping (the 
information effect). Hence, managers are likely to purchase their firm's shares in the open market more actively (insider trading) to generate a positive signal associated with diversification strategies.

At the same time, when managers implement diversification strategies, their propensity to purchase shares in their own firm also increases. There appears to be a positive relationship between the corporate diversification strategies of managers and their propensity to purchase shares in their own firm in the open market. Thus, if the information effect of corporate diversification dominates the agency effect, then:

Hypotheses $2(\mathrm{H} 2)$ : There exists a positive relationship between corporate diversification and insider trading.

\section{Sources of Data}

This paper analyzes the ordinary stocks of 12 industries listed on the Pakistan Stock Exchange. Of the 130 companies originally identified, we exclude 30 firms for lack of data on share transactions by corporate insiders, yielding a final sample of 100 companies. The sample construction is based on market capitalization. The sample period spans 10 years from 2005 to 2014. We look at stocks from the nonfinancial sector that have been traded for at least the past eight months.

The data was obtained from several sources. The accounting and financial data for entropy measures (corporate diversification) and the control variables was sourced from the Karachi Stock Exchange and Business Recorder websites. We have also used the State Bank of Pakistan's balance sheet analysis as a source of secondary data. The data on corporate insider trading (purchase and sale of shares) was collected from the annual reports of each company.

\section{Measurement of Variables}

This section explains the variables employed: corporate diversification, asymmetric information, insider trading. It also describes the control variables used.

\subsection{Corporate Diversification}

We use the corporate industrial entropy index to capture total diversification for several reasons: it is technically rigorous and has a strong theoretical base and fewer shortcomings than other measures of corporate 
diversification discussed in the literature (Sambharya, 2000). Jacquemin and Berry (1979) show that a fundamental advantage of the entropy measure over the Herfindahl index and other measures is that it decomposes diversification into related and unrelated components. This decomposition is important because, as Palich, Cardinal and Miller (2000) note, unrelated corporate diversification gives managers a greater chance to reduce the risk associated with their human capital. Hence, the agency effect of diversification is likely to be stronger in the case of unrelated corporate diversification. Following Clarke, Fee and Thomas (2004), Haultz et al. (2013) and Ataullah et al. (2014), we calculate the entropy index for total diversification as:

$$
I N D_{-} E N T_{i t-1}=\sum_{h=1}^{N} P_{h i t} \ln \left(1 / P_{h i t}\right)
$$

where $P_{\text {hit }}$ is the percentage of firm sales generated in industry segment $h$ in year $t$ and the summation over $N$ segments in which firm $i$ operates at the beginning of the year. The greater the value of entropy, the higher will be the level of diversification. The unrelated component of the entropy index $U N_{-} E N T_{i t-1}$ for firm $i$ in year $t$ is calculated as:

$$
U N_{-} E N T_{i t-1}=\sum_{s=1}^{K} P_{s i t} \ln \left(1 / P_{s i t}\right)
$$

where $P_{\text {sit }}$ is the percentage of firm sales generated by industry segment $s$ in year $t$ and the summation over $K$ industry segments in which firm $i$ operates at the beginning of the year.

The percentage of firm sales generated in industry segments (related and unrelated) is based on the 4-digit Pakistan Standard Industrial Classification. The industrial entropy index (total entropy) is slightly different from the unrelated component of the entropy index in the following way. In the case of total entropy $\left(I N D_{-} E N T_{i t-1}\right)$, we consider firm sales generated in both related and unrelated segments ( $N$ segments). In the case of unrelated entropy $\left(U N_{-} E N T_{i t-1}\right)$, firm sales generated in the unrelated segments ( $K$ industry segments) are considered. We define unrelated diversification as the firm being involved in different segments from its core activities. 


\subsection{Asymmetric Information}

Asymmetric information is captured through insiders' superior information on future performance. Following earlier studies, we construct a dummy variable $\left(G D R O A_{(i, t+1)}\right)$ that takes a value of 1 if the value of the next year's net income before extraordinary items divided by the total book value of assets is greater than the corresponding value for this year, and 0 otherwise (Piotroski \& Roulstone, 2005; Ataullah et al., 2014).

\subsection{Insider Trading}

Following Piotroski and Roulstone (2005), insider trading is captured using the purchase ratio, which is calculated as:

$$
P R_{i, t}=\frac{B u y_{i, t}}{B u y_{i, t}+\operatorname{Sell}_{i, t}}
$$

where $B u y_{i, t}$ is the number of shares purchased and $\left(B u y_{i, t}+S e l l_{i, t}\right)$ equals the total shares traded by the insiders (directors) of firm $i$ in year $t$. We use this purchase ratio in linear regressions as the dependent variable.

\subsection{Control Variables}

It is important to control the variables (other than the explanatory variables) that may influence insider trading to overcome omitted variable bias (Davidson \& MacKinnon, 2004). Firm leverage $\operatorname{Lev}_{(i, t-1)}$ is used as a control variable as debt holders are likely to monitor highly leveraged firms, which, in turn, may decrease information asymmetries (Harris \& Raviv, 1991). We use the ratio of long-term debt to the total market value of equity as a measure of firm leverage. Firm risk $F R_{(i, t-1)}$ is also used as a control variable because, as mentioned earlier, firm-specific risk can influence insider trading. Here, firm risk is measured as the standard deviation of daily returns for 180 days prior to the first day of the year on which an insider trades (Coff \& Lee, 2003).

Firm size $F S_{t-1}$ is used as a control variable because investors react to smaller firms more readily in terms of insider trading: insiders are seen as having greater access to the relevant information, which is signaled to the market through their frequent trade (Seyhun, 1986). We use the natural logarithm of market capitalization at the beginning of the year to measure firm size. Finally, R\&D expenditure $R \& D_{t-1}$ is also used as a control variable. Following Coff and Lee (2003), it is measured as a dummy variable that is 
equal to 1 if the firm's R\&D expenditure at the beginning of the year is non zero and 0 otherwise.

\section{Estimation Model}

Following the literature, we consider the link between corporate diversification and insider trading (see Krishnaswami \& Subramaniam, 1999; Clarke et al., 2004; Manne, 2005; Ataullah et al., 2014). The aim is to investigate the corporate diversification-value relationship under conditions of asymmetric information and insider trading. To this end, we estimate a fixed-effects panel data model. The choice of model is based on the likelihood ratio (common versus fixed effects) and Hausman test (fixed versus random effects).

Table 1 shows that, in both cases (cross-section and period), the null hypothesis is rejected for the likelihood ratio as well as the Hausman test. Accordingly, we use a firm-year fixed-effects model.

\section{Table 1: Choice between fixed and random effects models}

Test cross-section fixed effects (likelihood ratio)

\begin{tabular}{|c|c|c|c|}
\hline Effects test & Statistic & d.f. & Prob. \\
\hline Cross-section F & 8.455365 & $(99,894)$ & 0.0000 \\
\hline Cross-section chi-square & 660.795678 & 99 & 0.0000 \\
\hline \multicolumn{4}{|l|}{$\begin{array}{l}\text { Correlated random effects } \\
\text { (Hausman test) }\end{array}$} \\
\hline Test summary & Chi-sq. stat & Chi-sq. d.f. & \\
\hline Cross-section random & 113.186550 & 7 & 0.0000 \\
\hline \multicolumn{4}{|c|}{ Test period fixed effects (likelihood ratio) } \\
\hline Effects test & Statistic & d.f. & Prob. \\
\hline Period F & 2.056410 & $(9,983)$ & 0.0308 \\
\hline Period chi-square & 18.652711 & 9 & 0.0283 \\
\hline \multicolumn{4}{|l|}{$\begin{array}{l}\text { Test period random effects } \\
\text { (Hausman test) }\end{array}$} \\
\hline Test summary & Chi-sq. stat & Chi-sq. d.f. & \\
\hline Period random & 18.146532 & 7 & 0.0113 \\
\hline
\end{tabular}

Note: The following null and alternative hypotheses are tested: (i) for common versus fixed effects, $\mathrm{H}_{0}=$ common effects more appropriate, $\mathrm{H} 1$ = fixed effects more appropriate, (ii) for fixed versus random effects, $\mathrm{H} 0$ = random effects more appropriate, $\mathrm{H} 1$ = fixed effects more appropriate.

Source: Authors' calculations. 
To test $\mathrm{H} 1$ and $\mathrm{H} 2$ on corporate diversification (total and unrelated), information asymmetry and insider trading, we estimate the following regression equation:

$$
\begin{aligned}
P R_{i, t}= & \alpha_{i, t}+\beta_{1} \text { Ind }_{-} E n t_{i, t-1}+\beta_{2} U n_{-} E n t_{i, t-1}+\beta_{3} G D R O A_{i, t+1}+ \\
& \text { rcontrol } l_{i, t}+\varepsilon_{i, t}
\end{aligned}
$$

where $\beta_{1}, \beta_{2}$ and $\beta_{3}$ capture all variations in the dependent variable, $\gamma$ captures the effect of the control variables, $\alpha_{i, t}$ is the intercept and $\varepsilon_{i, t}$ is the error term.

\section{Empirical Results and Discussion}

Our sample size is limited to 1,000 firm-years (observations), given the availability of data for the selected variables. Table 2 presents the descriptive statistics for the data for the period 2005-14. The means of the total and unrelated entropy measures (corporate diversification) of diversified firm-years are 0.767 and 0.470 , respectively. The mean of the unrelated component of the entropy measure is about 61 percent of the mean of total entropy, which suggests a high level of unrelated diversification among the firms in the sample.

Most of the values are negatively skewed. If the kurtosis value is equal to 3 , then the normal distribution and pattern are mesokurtic. If the value is greater than 3 , then the pattern is leptokurtic, which is associated with a peaked, fat-tailed distribution. A kurtosis value of less than 3 is referred to as platykurtic and is associated with a less peaked distribution and thinner tail. Most of the values in Table 2 show leptokurtic behavior (greater than 3), with a maximum value of 8.796 and a minimum value of 1.000. The kurtosis values show that the data follows a peaked, fat-tailed distribution. 
Table 2: Summary statistics for firm-level attributes and insider trading

\begin{tabular}{lcccccccc}
\hline Statistic & $\boldsymbol{P R}_{\boldsymbol{i}, \boldsymbol{t}}$ & Ind_Ent $_{\boldsymbol{t} \mathbf{1}}$ & $\boldsymbol{U n}_{-} \boldsymbol{E n t} \boldsymbol{t}_{\mathbf{1}}$ & $\boldsymbol{G D R O A}_{\boldsymbol{t + 1} \mathbf{1}}$ & $\boldsymbol{F R}_{\boldsymbol{t}-\mathbf{1}}$ & $\boldsymbol{F} \boldsymbol{S}_{\boldsymbol{t}-\mathbf{1}}$ & $\boldsymbol{L e v}_{\boldsymbol{t}-\mathbf{1}}$ & $\boldsymbol{R} \& \boldsymbol{D}_{\boldsymbol{t}-\mathbf{1}}$ \\
\hline Mean & 0.508 & 0.767 & 0.470 & 0.905 & 0.758 & 8.526 & 1.168 & 0.493 \\
Median & 0.517 & 0.844 & 0.450 & 1.000 & 0.833 & 8.367 & 0.906 & 0.000 \\
Maximum & 1.000 & 1.180 & 0.880 & 1.000 & 0.968 & 13.910 & 5.670 & 1.000 \\
Minimum & 0.0008 & 0.003 & 0.039 & 0.000 & -0.239 & 2.332 & 0.010 & 0.000 \\
SD & 0.273 & 0.232 & 0.185 & 0.293 & 0.206 & 1.621 & 0.977 & 0.500 \\
Skewness & 0.010 & -1.630 & -0.021 & -2.762 & -2.495 & -0.012 & 1.035 & 0.028 \\
Kurtosis & 1.840 & 5.039 & 2.062 & 8.631 & 8.796 & 4.607 & 3.616 & 1.000 \\
Probability & 0.000 & 0.000 & 0.000 & 0.000 & 0.000 & 0.000 & 0.000 & 0.000 \\
Observ. & 1,000 & 1,000 & 1,000 & 1,000 & 1,000 & 1,000 & 1,000 & 1,000 \\
\hline
\end{tabular}

Note: See Table A1 in the Appendix for an industry classification of the sample.

Source: Authors' calculations.

Table 3 reports the results of multicollinearity checks. Panel A presents the correlation matrix and Panel B reports the variance inflation factors for the explanatory variables. There is a weak correlation among all the explanatory variables except firm risk and industrial entropy (0.603).

\section{Table 3: Multicollinearity checks}

Panel A: Correlation matrix

\begin{tabular}{|c|c|c|c|c|c|c|c|c|}
\hline Variable & $P R_{i, t}$ & Ind_Ent $_{t-1}$ & $\boldsymbol{U n}_{-} \mathrm{Ent}_{t-1}$ & $\operatorname{GDROA}_{t+1}$ & $F R_{t-1}$ & $F S_{t-1}$ & $L e v_{t-1}$ & $R \& D_{t-1}$ \\
\hline$P R_{i, t}$ & $1.000^{* * *}$ & & & & & & & \\
\hline Ind_Ent $_{t-1}$ & $0.088^{* * *}$ & 1.000 & & & & & & \\
\hline$U n_{-} E n t_{t-1}$ & $0.356^{* * *}$ & 0.331 & 1.000 & & & & & \\
\hline$G D R O A_{t+1}$ & $0.010^{* * *}$ & -0.079 & -0.025 & 1.000 & & & & \\
\hline$F R_{t-1}$ & $-0.084^{* * *}$ & 0.603 & 0.376 & -0.058 & 1.000 & & & \\
\hline$F S_{t-1}$ & $-0.168^{* * *}$ & 0.279 & 0.073 & -0.088 & 0.288 & 1.000 & & \\
\hline$L e v_{t-1}$ & $0.542^{* * *}$ & -0.206 & 0.175 & 0.001 & -0.192 & -0.183 & 1.000 & \\
\hline$R \& D_{t-1}$ & -0.062 & -0.227 & -0.062 & -0.001 & -0.180 & 0.193 & 0.039 & 1.000 \\
\hline
\end{tabular}

Panel B: Variance inflation factors

\begin{tabular}{lccc}
\hline Variable & Coefficient variance & Un-centered VIF & Centered VIF \\
\hline Ind_Ent $_{t-1}$ & 0.0013 & 20.3550 & 1.7091 \\
Un_Ent $_{t-1}$ & 0.0017 & 10.7990 & 1.4546 \\
$G D R O A_{t+1}$ & 0.0004 & 10.6510 & 1.0118 \\
$F R_{t-1}$ & 0.0019 & 28.5340 & 1.9695 \\
$F S_{t-1}$ & $2.00 \mathrm{E}-0$ & 35.6140 & 1.2421 \\
$L e v_{t-1}$ & $5.25 \mathrm{E}-0$ & 2.8809 & 1.1846 \\
$R \& D_{t-1}$ & 0.0001 & 2.2843 & 1.1581 \\
Const. & 0.0023 & 55.8930 & 0.0000 \\
\hline
\end{tabular}

Note: ${ }^{* * *}$ and ${ }^{* *}=$ coefficient is statistically significant at $5 \%$ and $10 \%$, respectively. Source: Authors' calculations. 
For further confirmation, the variance inflation factors are computed as $\operatorname{VIF} q=1 /(1-q)$, where $q$ is the correlation coefficient obtained by regressing the explanatory variable $q$ on all the remaining explanatory variables in the model. The results are essentially free of any serious multicollinearity among the explanatory variables. The variance inflation factors reported in Panel B range from 1.0118 to 1.9695, showing there is no significant multicollinearity among the explanatory variables.

Table 4 reports the results for insider trading and corporate diversification, using multivariate regression analysis. We use linear panel data models with both firm and year fixed effects to estimate the results. Most of the control variables have the expected signs. The coefficient of firm size $\left(F S_{t-1}\right)$ is negative and significantly different from 0 , suggesting that, with an increase in firm size, insider trading falls. This finding is consistent with earlier studies (see Seyhun, 1986; Jeng et al., 2003). Firm risk $F R_{t-1}$ and leverage $L e v_{t-1}$ are positive and significantly different from 0 , suggesting that insider trading increases with a rise in firm-specific risk and leverage. These results are in line with the findings of Coff and Lee (2003) and Harris and Raviv (1991).

Table 4: Insider trading and corporate diversification (linear panel firm and year fixed effects)

\begin{tabular}{lcccc}
\hline Variable & Coefficient & SE & t-value & Prob. \\
\hline Ind_Ent $_{t-1}$ & $0.322^{* * *}$ & 0.047 & 6.804 & 0.000 \\
Un_Ent & $0.404^{* * *}$ & 0.074 & 5.448 & 0.000 \\
$G D R O A_{t+1}$ & $0.034^{* *}$ & 0.020 & 1.712 & 0.087 \\
$F R_{t-1}$ & $0.282^{* * *}$ & 0.085 & 3.310 & 0.001 \\
$F S_{t-1}$ & $-0.046^{* * *}$ & 0.014 & -3.224 & 0.001 \\
$L e v_{t-1}$ & $0.042^{* * *}$ & 0.008 & 5.123 & 0.000 \\
$R \& D_{t-1}$ & -0.005 & 0.020 & -0.264 & 0.791 \\
Const. & 0.172 & 0.151 & 1.141 & 0.253 \\
\hline Adj. R2 & 0.680 & & & \\
F-statistic & 19.700 & & & \\
F (p-value) & 0.000 & & & \\
\hline
\end{tabular}

Note: The dependent variable is the purchase ratio $\left(P R_{i, t}\right)$. The independent variables are total diversification (Ind_Ent $\left.t_{t-1}\right)$, unrelated diversification $\left(U n_{-} E n t_{t-1}\right)$ and asymmetric information $\left(G D R O A_{t+1}\right){ }^{* * *}$ and ${ }^{* *}=$ coefficient is statistically significant at $5 \%$ and $10 \%$, respectively. See Table A2 in the Appendix for individual firm and year fixed effects.

Source: Authors' calculations. 
The explanatory variables are total industrial diversification $\left(\right.$ Ind_Ent $\left._{t-1}\right)$, unrelated industrial diversification $\left(U n_{-} E n t_{t-1}\right)$ and asymmetric information $\left(G D R O A_{i, t+1}\right)$. The coefficients of total and unrelated diversification are positive and statistically significant at the 95 percent significance level. The coefficient of asymmetric information is positive and statistically significant at the 90 percent significance level.

Overall, the effect of corporate diversification holds even after controlling for other variables and our results based on the intensity of insider purchases support the theory of the information effect of diversification. This is because the findings suggest that when insiders implement diversification strategies with the intention of increasing the value of their firm, they also increase their own purchase of the firm's shares, particularly when they believe that outside investors may undervalue their strategies due to information asymmetries (the information effect). This is consistent with $\mathrm{H} 2$, but inconsistent with $\mathrm{H} 1$. Thus, the information effect of corporate diversification holds for the Pakistani stock market.

These findings are similar to those in the literature (see Krishnaswami \& Subramaniam, 1999; Clarke et al., 2004; Ataullah et al., 2014). As with other studies, we consider insiders to be executive directors because they have substantial exposure to their equity via the firm's executive compensation schemes (Conyon, Core \& Guay, 2011). Hence, their willingness to buy shares in their own firm in the open market in the case of high diversification is a strong indicator of the information effect of corporate diversification. However, nonexecutive directors do not seem to purchase more shares when undervaluation by outside investors is high because they are not as close to the firm as its executive directors.

\section{Summary and Conclusion}

The discussion above shows that there are two different views on implementing diversification strategies by corporate insiders and its impact on firm value. The agency theory-based view argues that managers implement diversification strategies to gain personal benefits rather than to increase the firm's value. The alternative view is that corporate diversification is a useful strategic decision that helps improve firm value, but is not valued optimally by outside investors due to information asymmetries.

The two views have different implications for corporate policies and the management literature. In terms of the agency effect, corporate diversification is considered a value-destructive strategy. Therefore, further 
work is needed to improve the corporate governance system to ensure that managerial decision making focuses on enhancing firm value. In terms of the information effect, corporate diversification is not considered a valuedecreasing strategy if the firm's managers are able to generate positive signals to external shareholders.

Our analysis is based on the literature on insider trading and supports the information effect of diversification. We suggest that insiders consider their strategies to enhance value and try to deliver this information to outside shareholders by purchasing their own firm's shares in the open market. In the Pakistani stock market, the information effect of diversification dominates the agency effect because its financial markets are characterized by high information asymmetries and market inefficiencies.

This result is supported by Morck, Yeung and Yu (2000) and Alves, Peasnell and Taylor (2010), who find that poorer economies tend to have high information asymmetries and market inefficiencies such as less robust legal investor protection and disclosure systems. These information asymmetries and market inefficiencies, in turn, enhance the existence of the information effect in developing countries. Hence, it is necessary to help managers develop strong mechanisms to improve the information asymmetries associated with their diversification strategies. Managers also need to communicate the value of their diversification strategies to outside investors rather than simply focusing on governance mechanisms. This can be done by improving information disclosure mechanisms and investor protection laws in the stock markets of developing countries.

Future research could take the following directions: First, it could investigate why the agency effect of corporate diversification seems to be disappearing over time. What possible factors may have transformed the agency effect into the information effect of corporate diversification? Second, this study is limited to one developing country. It could be extended to a larger sample to provide a cross-country comparison. 


\section{References}

Afza, T., Slahudin, C., \& Nazir, M. S. (2008). Diversification and corporate performance: An evaluation of Pakistani firms. South Asian Journal of Management, 15(3), 7-18.

Agarwal, M., \& Singh, H. (2006). Merger announcements and insider trading activity in India: An empirical investigation. Investment Management and Financial Innovations, 3(3), 140-154.

Aggarwal, R. K., \& Samwick, A. A. (2003). Why do managers diversify their firms? Agency reconsidered. Journal of Finance, 58(1), 71-118.

Alldredge, D. M., \& Cicero, D. C. (2015). Attentive insider trading. Journal of Financial Economics, 115(1), 84-101.

Alves, P., Peasnell, K., \& Taylor, P. (2010). The use of the R2 as a measure of firm-specific information: A cross-country critique. Journal of Business Finance and Accounting, 37(1-2), 1-26.

Amihud, Y., \& Lev, B. (1981). Risk reduction as a managerial motive for conglomerate mergers. Bell Journal of Economics, 12(2), 605-617.

Anderson, R. C., \& Reeb, D. M. (2003). Founding-family ownership, corporate diversification and firm leverage. Journal of Law and Economics, 46(2), 653-684.

Ataullah, A., Davidson, I., Le, H., \& Wood, G. (2014). Corporate diversification, information asymmetry and insider trading. British Journal of Management, 25(2), 228-251.

Berger, P. G., \& Ofek, E. (1995). Diversification's effect on firm value. Journal of Financial Economics, 37(1), 39-65.

Claessens, S., Djankov, S., Fan, J. P., \& Lang, H. P. (1998). Diversification and efficiency of investment by East Asian corporations (Policy Research Working Paper No. 2033). Washington, DC: World Bank.

Clarke, J. E., Fee, C. E., \& Thomas, S. (2004). Corporate diversification and asymmetric information: Evidence from stock market trading characteristics. Journal of Corporate Finance, 10(1), 105-129. 
Coff, R. W., \& Lee, P. M. (2003). Insider trading as a vehicle to appropriate rent from R\&D. Strategic Management Journal, 24(2), 183-190.

Conyon, M. J., Core, J. E., \& Guay, W. R. (2011). Are US CEOs paid more than UK CEOs? Inferences from risk-adjusted pay. Review of Financial Studies, 24(2), 402-438.

Custodio, C. (2014). Mergers and acquisitions accounting and the diversification discount. Journal of Finance, 69(1), 219-240.

Cziraki, P., De Goeij, P., \& Renneboog, L. (2014). Corporate governance rules and insider trading profits. Review of Finance, 18(1), 67-108.

Damodaran, A., \& Liu, C. H. (1993). Insider trading as a signal of private information. Review of Financial Studies, 6(1), 79-119.

Davidson, R., \& MacKinnon, J. G. (2004). Econometric theory and methods. New York: Oxford University Press.

Davis, J. H., Schoorman, F. D., \& Donaldson, L. (1997). Toward a stewardship theory of management. Academy of Management Review, 22(1), 20-47.

Denis, D. J., Denis, D. K., \& Sarin, A. (1997). Agency problems, equity ownership and corporate diversification. Journal of Finance, 52(1), 135-160.

Denis, D. J., Denis, D. K., \& Yost, K. (2002). Global diversification, industrial diversification and firm value. Journal of Finance, 57(5), 1951-1979.

Doukas, J. A., \& Kan, O. B. (2006). Does global diversification destroy firm value? Journal of International Business Studies, 37(3), 352-371.

Erdorf, S., Hartmann-Wendels, T., Heinrichs, N., \& Matz, M. (2013). Corporate diversification and firm value: A survey of recent literature. Financial Markets and Portfolio Management, 27(2), 187-215.

Fama, E. F., \& Jensen, M. C. (1983). Agency problems and residual claims. Journal of Law and Economics, 26(2), 327-349.

Fauver, L., Houston, J., \& Naranjo, A. (2003). Capital market development, international integration, legal systems and the value of corporate 
diversification: A cross-country analysis. Journal of Financial and Quantitative Analysis, 38(1), 135-158.

Fidrmuc, J. P., Goergen, M., \& Renneboog, L. (2006). Insider trading, news releases and ownership concentration. Journal of Finance, 61(6), 2931-2973.

Fox, M. A., \& Hamilton, R. T. (1994). Ownership and diversification: Agency theory or stewardship theory. Journal of Management Studies, 31(1), 69-81.

Frankel, R., \& Li, X. (2004). Characteristics of a firm's information environment and the information asymmetry between insiders and outsiders. Journal of Accounting and Economics, 37(2), 229-259.

Gomez-Mejia, L. R., \& Wiseman, R. M. (2007). Does agency theory have universal relevance? A reply to Lubatkin, Lane, Collin and Very. Journal of Organizational Behavior, 28(1), 81-88.

Grigorieva, S., \& Petrunina, T. (2015). The performance of mergers and acquisitions in emerging capital markets: New angle. Journal of Management Control, 26(4), 377-403.

Hadlock, C. J., Ryngaert, M., \& Thomas, S. (2001). Corporate structure and equity offerings: Are there benefits to diversification? Journal of Business, 74(4), 613-635.

Harris, M., \& Raviv, A. (1991). The theory of capital structure. Journal of Finance, 46(1), 297-355.

Hoechle, D., Schmid, M., Walter, I., \& Yermack, D. (2012). How much of the diversification discount can be explained by poor corporate governance? Journal of Financial Economics, 103(1), 41-60.

Hund, J., Monk, D., \& Tice, S. (2010). Uncertainty about average profitability and the diversification discount. Journal of Financial Economics, 96(3), 463-484.

Jacquemin, A. P., \& Berry, C. H. (1979). Entropy measure of diversification and corporate growth. Journal of Industrial Economics, 27(4), 359-369. 
Jagolinzer, A. D., Larcker, D. F., \& Taylor, D. J. (2011). Corporate governance and the information content of insider trades. Journal of Accounting Research, 49(5), 1249-1274.

Jeng, L. A., Metrick, A., \& Zeckhauser, R. (2003). Estimating the returns to insider trading: A performance-evaluation perspective. Review of Economics and Statistics, 85(2), 453-471.

Jensen, M. C. (1988). Takeovers: Their causes and consequences. Journal of Economic Perspectives, 2(1), 21-48.

Jensen, M. C., \& Meckling, W. H. (1976). Theory of the firm: Managerial behavior, agency costs and ownership structure. Journal of Financial Economics, 3(4), 305-360.

Jensen, M. C., \& Murphy, K. J. (1990). Performance pay and topmanagement incentives. Journal of Political Economy, 98(2), 225-264.

John, K., \& Lang, L. H. (1991). Insider trading around dividend announcements: Theory and evidence. Journal of Finance, 46(4), 1361-1389.

Joseph, K., \& Wintoki, M. B. (2013). Advertising investments, information asymmetry and insider gains. Journal of Empirical Finance, 22, 1-15.

Krishnaswami, S., \& Subramaniam, V. (1999). Information asymmetry, valuation and the corporate spin-off decision. Journal of Financial Economics, 53(1), 73-112.

Lane, P. J., Cannella, A. A., \& Lubatkin, M. H. (1998). Agency problems as antecedents to unrelated mergers and diversification: Amihud and Lev reconsidered. Strategic Management Journal, 19(6), 555-578.

Lang, L. H., \& Stulz, R. M. (1994). Tobin's q, corporate diversification and firm performance. Journal of Political Economy, 102(6), 1248-1280.

Lins, K., \& Servaes, H. (1999). International evidence on the value of corporate diversification. Journal of Finance, 54(6), 2215-2240.

Lins, K. V., \& Servaes, H. (2002). Is corporate diversification beneficial in emerging markets? Financial Management, 31(2), 5-31. 
Manne, H. G. (2005). Insider trading: Hayek, virtual markets and the dog that did not bark. Journal of Corporation Law, 31(1), 167-185.

Mansi, S. A., \& Reeb, D. M. (2002). Corporate diversification: What gets discounted? Journal of Finance, 57(5), 2167-2183.

Martin, J. D., \& Sayrak, A. (2003). Corporate diversification and shareholder value: A survey of recent literature. Journal of Corporate Finance, 9(1), 37-57.

McConnell, J. J., McKeon, S. B., \& Xu, W. (2010). Corporate governance and ownership structure. In H. K. Baker \& R. Anderson (Eds.), Corporate governance: A synthesis of theory, research and practice (pp. 303-322). Hoboken, NJ: Wiley.

Morck, R., Yeung, B., \& Yu, W. (2000). The information content of stock markets: Why do emerging markets have synchronous stock price movements? Journal of Financial Economics, 58(1-2), 215-260.

Palich, L. E., Cardinal, L. B., \& Miller, C. C. (2000). Curvilinearity in the diversification-performance linkage: An examination of over three decades of research. Strategic Management Journal, 21(2), 155-174.

Piotroski, J. D., \& Roulstone, D. T. (2005). Do insider trades reflect both contrarian beliefs and superior knowledge about future cash flow realizations? Journal of Accounting and Economics, 39(1), 55-81.

Qureshi, M. A., Akhtar, W., \& Imdadullah, M. (2012). Does diversification affect capital structure and profitability in Pakistan? Asian Social Science, 8(4), 30-42.

Rozeff, M. S., \& Zaman, M. A. (1998). Overreaction and insider trading: Evidence from growth and value portfolios. Journal of Finance, 53(2), 701-716.

Rudolph, C., \& Schwetzler, B. (2013). Conglomerates on the rise again? A cross-regional study on the impact of the 2008-2009 financial crisis on the diversification discount. Journal of Corporate Finance, 22, 153165.

Sambharya, R. B. (2000). Assessing the construct validity of strategic and SIC-based measures of corporate diversification. British Journal of Management, 11(2), 163-173. 
Seyhun, H. N. (1986). Insiders' profits, costs of trading and market efficiency. Journal of Financial Economics, 16, 189-212.

Shleifer, A., \& Vishny, R. W. (1989). Management entrenchment: The case of manager-specific investments. Journal of Financial Economics, 25(1), 123-139.

Skaife, H. A., Veenman, D., \& Wangerin, D. (2013). Internal control over financial reporting and managerial rent extraction: Evidence from the profitability of insider trading. Journal of Accounting and Economics, 55(1), 91-110.

Thomas, S. (2002). Firm diversification and asymmetric information: Evidence from analysts' forecasts and earnings announcements. Journal of Financial Economics, 64, 373-396.

Tsai, L.-C., Young, C.-S., \& Hsu, H.-W. (2011). Entrenched controlling shareholders and the performance consequences of corporate diversification in Taiwan. Review of Quantitative Finance and Accounting, 37(1), 105-126.

Zahavi, T., \& Lavie, D. (2013). Intra-industry diversification and firm performance. Strategic Management Journal, 34(8), 978-998. 
Appendix

Table A1: Industry classification of sample

\begin{tabular}{lcc}
\hline Industry & $\begin{array}{c}\text { Number of firms in } \\
\text { the sample }\end{array}$ & $\begin{array}{c}\text { Firm-year } \\
\text { observations }\end{array}$ \\
\hline Automobiles and parts & 8 & 80 \\
Chemicals & 10 & 100 \\
Construction and materials & 12 & 120 \\
Electricity & 9 & 90 \\
Foods & 10 & 100 \\
Household goods & 3 & 30 \\
Industrial engineering & 2 & 20 \\
Industrial metals and mining & 2 & 20 \\
Oil and gas & 8 & 80 \\
Pharma & 4 & 40 \\
Sugar & 14 & 140 \\
Textiles & 18 & 180 \\
Total & 100 & 1,000 \\
\hline
\end{tabular}

Note: The industries above are all listed on the Pakistan Stock Exchange.

Table A2: Individual firm and year fixed effects

\begin{tabular}{lrlr}
\hline \multicolumn{1}{c}{ Fixed effects (cross) } & \multicolumn{1}{c}{ Fixed effects (cross) } \\
\hline AABS-C & -0.366779 & HSPIL-C & -0.163921 \\
AASM-C & -0.150153 & ICCT-C & -0.157730 \\
ABOT-C & 0.223289 & ICI-C & 0.234418 \\
ADML-C & 0.076374 & ICL-C & -0.110949 \\
ADTM-C & 0.078566 & IFPL-C & -0.205969 \\
ALNRS-C & -0.025167 & IIL-C & -0.136200 \\
ALQT-C & 0.156339 & ISTM-C & -0.152377 \\
ANL-C & -0.143781 & JVDC-C & -0.305378 \\
APOT-C & -0.172393 & KML-C & 0.252924 \\
ARUJ-C & -0.086396 & KOHC-C & 0.108906 \\
ASHT-C & -0.217751 & KOHTM-C & 0.282442 \\
ATBA-C & 0.061465 & KOSM-C & 0.273080 \\
ATRL-C & 0.045780 & KSBP-C & -0.356770 \\
AYTM-C & 0.071487 & KSTM-C & -0.349877 \\
AZTM-C & 0.081571 & KTML-C & -0.187694 \\
BERG-C & -0.014222 & LPGL-C & 0.017928 \\
BPL-C & 0.144930 & LUCK-C & 0.005209 \\
\hline
\end{tabular}




\begin{tabular}{|c|c|c|c|}
\hline \multicolumn{2}{|c|}{ Fixed effects (cross) } & \multicolumn{2}{|c|}{ Fixed effects (cross) } \\
\hline BROT-C & -0.123699 & MEHT-C & 0.001480 \\
\hline BTL-C & 0.245100 & MLCF-C & 0.039838 \\
\hline BWL-C & 0.052287 & MRNS-C & -0.266328 \\
\hline CHAS-C & -0.121773 & MTL-C & -0.052378 \\
\hline $\mathrm{CHCC}-\mathrm{C}$ & -0.367214 & MUREB-C & 0.130896 \\
\hline COST-C & -0.102350 & NFL-C & 0.051665 \\
\hline CPL-C & -0.215821 & NMFL-C & -0.265625 \\
\hline CSML-C & 0.222787 & NONS-C & 0.055747 \\
\hline CWSM-C & 0.112035 & NPL-C & -0.004566 \\
\hline DBL-C & 0.116730 & NRL-C & -0.004695 \\
\hline DEL-C & -0.233010 & PEL-C & -0.341133 \\
\hline DGKC-C & 0.129245 & PGCL-C & 0.202402 \\
\hline DINT-C & -0.142102 & PIOC-C & 0.027350 \\
\hline DKTM-C & -0.171910 & PLCL-C & 0.080227 \\
\hline DMTM-C & -0.097172 & PNGRS-C & 0.201899 \\
\hline DSML-C & 0.018234 & POML-C & -0.147433 \\
\hline DWSM-C & -0.185039 & RMPCL-C & 0.055779 \\
\hline DWTM-C & 0.052401 & SANSM-C & -0.002618 \\
\hline EIL-C & 0.006112 & SAPL-C & -0.136729 \\
\hline FAEL-C & -0.046782 & SARC-C & 0.059786 \\
\hline FASM-C & 0.010733 & SEARL-C & 0.157733 \\
\hline FCCL-C & -0.208745 & SECL-C & -0.108572 \\
\hline FZCM-C & 0.143214 & SGML-C & -0.061504 \\
\hline GADT-C & 0.059753 & SHEL-C & 0.542367 \\
\hline GFIL-C & -0.065207 & SHEZ-C & 0.665084 \\
\hline GLAT-C & -0.348257 & SHSML-C & 0.434174 \\
\hline GLAXO-C & 0.120699 & SIL-C & 0.444770 \\
\hline GUSM-C & -0.218251 & SITC-C & 0.345098 \\
\hline HABSM-C & -0.132381 & SSOM-C & 0.361044 \\
\hline HAL-C & -0.271440 & STCL-C & 0.247262 \\
\hline HCCL-C & -0.326373 & SURAJ-C & 0.404479 \\
\hline HIL-C & -0.067201 & TICL-C & 0.061950 \\
\hline HINOON-C & -0.351065 & WYETH-C & 0.515807 \\
\hline \multicolumn{4}{|c|}{ Fixed effects (period) } \\
\hline 2005-C & -0.012313 & $2010-C$ & 0.022845 \\
\hline $2006-C$ & -0.027391 & 2011-C & 0.025648 \\
\hline 2007-C & -0.042210 & 2012-C & 0.022441 \\
\hline $2008-C$ & -0.025654 & 2013-C & -0.015614 \\
\hline 2009-C & 0.079521 & 2014-C & -0.027274 \\
\hline
\end{tabular}

